\title{
Altitudinal distribution, habitat use, and abundance of Grallaria antpittas in the Central Andes of Colombia
}

\author{
GUSTAVO H. KATTAN and J. WILLIAM BELTRAN
}

\section{Summary}

Grallaria antpittas are a group of little known birds from the understorey of humid forests of the tropical Andes, with several species having very narrow distributions. At Ucumari Regional Park, which protects the Otún River watershed in the Central Andes of Colombia, five species occur sympatrically at $2,400 \mathrm{~m}$, including the recently rediscovered G. milleri, of which this is the only known population. We studied the patterns of altitudinal distribution, habitat use and abundance of the five species in the park. We found altitudinal segregation at a local scale, with two species, G. ruficapilla and $G$. squamigera, found at lower elevations $(1,800-2,500 \mathrm{~m})$ and two other species, G. muchalis and G. rufocinerea, at higher elevations $(2,400-3,000)$; G. milleri was recorded only in the $2,400-2,600 \mathrm{~m}$ range. The five species overlap in the range $2,400-2,600 \mathrm{~m}$, where they occur in three habitats: early regeneration, overgrown alder plantations and 3o-year-old forest. There were no differences in density among habitats for any species; the five species used the three habitats in proportion to their occurrence in the landscape. Grallaria milleri had the highest overall density ( $1.3 \mathrm{ind} / \mathrm{ha}$ ) while G. squamigera had the lowest density ( $0.2 \mathrm{ind} / \mathrm{ha}$ ), and the other three species were intermediate. We estimated 106 individuals of $G$. milleri in an area of 63 ha, and only seven individuals of G. squamigera. The Otún River watershed concentrates an unusual number of Grallaria antpittas, including three endemic species, and the information presented here is fundamental to any future habitat management plans to ensure the persistence of these populations.

El género Grallaria está compuesto por aves muy poco conocidas del suelo de los bosques húmedos de los Andes tropicales, varias de las cuales tienen distribuciones geográficas muy estrechas. En el Parque Regional Ucumarí, el cual protege la cuenca del río Otún en la Cordillera Central de Colombia, existen cinco especies en simpatría a una elevación de 2,400 m; una de ellas es G. milleri, especie recientemente redescubierta, siendo esta hasta ahora la única población conocida. Realizamos un estudio de los patrones de distribución altitudinal, uso de hábitat y abundancia de las cinco especies en el parque. Encontramos segregación altitudinal a escala local, con dos especies, G. ruficapilla y $G$. squamigera, distribuidas en la parte baja del parque $(1,800-2,500 \mathrm{~m})$ y otras dos especies, G. rufocinerea y $G$. nuchalis, en la parte alta $(2,400-3,000 \mathrm{~m})$; G. milleri fue registrada solo en el rango de $2,400-2,600 \mathrm{~m}$. Las distribuciones de las cinco especies se superponen en el rango de $2,400-2,600 \mathrm{~m}$, en donde están en tres tipos de hábitat: rastrojos de regeneración temprana, bosques sembrados de aliso (Alnus acuminata) y bosques secundarios de 30 años. No encontramos diferencias en densidad entre hábitats para ninguna de las especies; las cinco especies usan los tres hábitats en proporción a su cobertura en el paisaje. Grallaria milleri tiene la densidad más alta ( 1.3 ind./ha), mientras que G. squamigera tiene la más baja (o.2 ind./ha) y las otras tres son intermedias. Estimamos 106 individuos de G. milleri 
y solo 7 de G. squamigera en un área de 63 ha. La cuenca del río Otún concentra un alto número de especies de Grallaria, incluyendo tres especies endémicas, por lo que la información obtenida en este estudio es fundamental para futuros planes de manejo de hábitat que aseguren la persistencia de estas poblaciones.

\section{Introduction}

The ground antbirds, family Formicariidae, are a group of little-known birds from the understorey of humid Neotropical forests. The group reaches its maximum diversity in the tropical Andes, where it is represented mainly by the genus Grallaria. Of the 30 species of Grallaria known from South America, 26 are Andean, with altitudinal ranges that start above $800 \mathrm{~m}$ (Ridgely and Tudor 1994).

Grallaria antpittas are noteworthy for exhibiting high levels of endemism. Fourteen Andean species have very restricted geographic distributions, being known from only one or a few localities (Ridgely and Tudor 1994). This may simply reflect poor knowledge, as antpittas are very secretive and inhabit dense undergrowth, which makes them very difficult to record. Although fieldwork in previously unexplored regions is filling gaps in the geographical distribution of some species (e.g. Stiles and Alvarez-López 1995), antpittas remain one of the most elusive and least-known groups of Neotropical birds. This is reflected in the fact that several new species have been discovered in the past 30 years (e.g. Graves 1987, Schulenberg and Williams 1982), and in one case not far from a large urban centre (Stiles 1992).

At Ucumarí Regional Park, which protects the Otún River watershed in the Central Andes of Colombia, five species of antpitta occur sympatrically at an elevation of $2,400 \mathrm{~m}$, including the recently rediscovered Brown-banded Antpitta G. milleri (Kattan and Beltrán 1997). Because this is so far the only known population of Brown-banded Antpitta, this species is highly vulnerable. Another species occurring at Ucumarí, the Bicolored Antpitta G. rufocinerea, is also endemic to the Central Andes and, although its status is indeterminate, it is considered in need of attention (Collar et al. 1992). The other three species, Undulated G. squamigera, Chestnut-crowned G. ruficapilla, and Chestnut-naped Antpitta G. muchalis, are more widely distributed in the Andes from Colombia and Venezuela, south to Peru and Bolivia. Ucumarí, therefore, provides a valuable opportunity for a comparative study of antpitta ecology.

Here we present results of a study that had the objectives of (1) determining the altitudinal ranges of the five species in the Otun River watershed, (2) determining whether the species differed in their patterns of habitat use in the area of overlap, and (3) comparing the local abundances of the five species. Because the syntopy of congeners raises the possibility of competition, we examined the degree of morphological similarity in traits that may be related to resource use.

\section{Study area and methods}

Ucumarí Regional Park ( $4^{\circ} 44^{\prime} \mathrm{N} 75^{\circ} 36^{\prime} \mathrm{W}$ ) is a 4,240 -ha watershed protection area, located east of the city of Pereira, on the western slope of the Central Andes of Colombia. The park protects the slopes of the Otún River between elevations of 1,800 and $2,600 \mathrm{~m}$. At this elevation the river runs through a narrow glacier valley 
with very steep slopes and numerous streams. At its upper limit, Ucumari abuts the 38,ooo-ha Los Nevados National Park, which protects higher elevations. Ucumarí is the only watershed in the Los Nevados area that provides almost continuous forest cover down to $1,800 \mathrm{~m}$. Below the lower limit of the park, forests are highly fragmented.

Before the initiation of protection programmes in the 1960s, the Ucumarí area was deforested and dedicated to extensive cattle ranching (Londoño 1994). Forests remained only on the steepest slopes and in some subsidiary canyons. Three decades ago, regional government organizations began purchasing private lands and initiated revegetation programmes. Some areas were planted with monospecific stands of native alder Alnus acuminata at the upper elevations $(2,200-$ $2,600 \mathrm{~m})$ and exotic ash Fraxinus chinensis at lower elevations $(1,800-2,000 \mathrm{~m})$ but most pasture areas were allowed to regenerate naturally. Tree plantations were not managed and are presently overgrown with native vegetation, in particular alder stands (Murcia 1997). Ucumarí is a multiple-use management area, with some small private holdings still included in the park. Therefore, at present, Ucumarí has a very heterogeneous landscape formed by a patchwork of small pastures, overgrown tree plantations and different-aged forest stands (Londoño 1994).

The study was conducted between May 1996 and April 1997. To determine altitudinal ranges of antpittas, we conducted monthly surveys along the $10-\mathrm{km}$ main park trail between 2,000 and 3,000 $\mathrm{m}$ elevation. This trail runs parallel to the river and cuts across a wide variety of habitats. In these surveys we counted singing birds and recorded the elevation, to determine the highest and lowest elevation for each species. To obtain data on habitat use and local abundance, we conducted detailed censuses at the site known as La Pastora, between elevations of 2,400 and $2,600 \mathrm{~m}$, where the five species of antpitta co-occur. At this site we selected three censusing routes totalling $6.3 \mathrm{~km}$, that criss-crossed the study area. These routes were censused once a month and the positions of singing birds were located on a map. The three routes covered three major habitat types:

(1) Early regeneration: early second growth vegetation, 15 years old or less, with a dense undergrowth of herbs, and a canopy of shrubs $2-5 \mathrm{~m}$ tall.

(2) Second growth forest: 30-year-old regeneration forest, with a canopy $15-20 \mathrm{~m}$ tall, irregular layers of foliage stratification, and abundance of epiphytes (Rangel and Garzón 1994, Murcia 1997).

(3) Alder stands: patches of 30-year-old alder plantations, with a rather homogeneous canopy 15-20 m tall, and with understorey growth typical of early to mid-regeneration stages (Murcia 1997).

It was not possible to establish transects along a single habitat type, as these habitats do not occur as discrete patches of appreciable size; instead, the three habitats are interspersed in a complex mosaic. We drew maps of the censusing routes and divided them into 10 500-m transects, separated by intervals of $50 \mathrm{~m}$. For each transect, we estimated the amount of cover of each habitat type, based on a 100-m-wide strip. We took each transect as an independent and representative sample of the landscape in our study area.

Censuses were conducted mainly by listening for antpitta songs given spontaneously, or in response to tape recordings of the species' songs. We recorded 
Table I. Altitudinal ranges (in metres) of antpittas in the 2,000-3,000 $\mathrm{m}$ transect at Ucumari, and in the Andes of Colombia

\begin{tabular}{lcc}
\hline Species & This study & Hilty and Brown (1986) \\
\hline G. ruficapilla & $2,000-2,550$ & $1,700-2,800$ \\
G. rufocinerea & $2,400-3,000$ & $2,100-3,100$ \\
G. nuchalis & $2,350-3,000$ & $2,200-3,000$ \\
G. milleri & $2,400-2,600$ & $2,700-3,100$ \\
G. squanigera & $2,000-2,550$ & $2,300-3,800$ \\
\hline
\end{tabular}

antpitta vocalizations with a Sony TCM-5000EV recorder, equipped with a Sennheiser ME66 cardioid microphone. Playbacks were made at least at $100-\mathrm{m}$ intervals, to avoid drawing birds from neighbouring territories to the recording. The position of each singing bird was marked at a point we estimated was perpendicular to the transect, and plotted on a map.

To complement visual and auditory records, and to obtain morphometric data, we captured birds with mist-nets. We operated 12 to 18 nets from dawn to dusk, in places where we had previously located singing birds. We placed nets in contact with the ground and well hidden in dense vegetation, and played back recordings to attract the birds. All captured birds were weighed, measured, colour-banded, and released.

To analyse patterns of habitat use, we determined the habitat in which each bird was located, and the number of individuals of each species per habitat type per transect. Because each habitat was represented in different proportions in each of the 10 transects, we standardized by calculating the number of individuals per $500 \mathrm{~m}$ for each habitat, and then averaged the 10 transects. Differences in density (number of individuals per $500 \mathrm{~m}$ ) among habitats were analysed with one-way analysis of variance (ANOVA) for each species. We also analysed whether the proportion of individuals of each species in each habitat was different from the expected, based on the proportion of occurrence of each habitat, with a chi-square test.

To obtain an estimate of population density, we used the fixed-width transect method (Franzreb 1981). We estimated the maximum distance that we considered allowed us to locate a singing bird with reasonable precision. Area sampled by the transects was calculated as the length of the transect multiplied by double the detection distance. Because of differences in song intensity, we estimated a maximum detection distance of $30 \mathrm{~m}$ for G. rufocinerea and G. squamigera, and $50 \mathrm{~m}$ for G. milleri, G. ruficapilla, and G. nuchalis. Densities are presented as the mean for the three transects. Total densities for the three habitats combined were compared among species with one-way ANOVA.

\section{Results}

The five antpitta species differed in their altitudinal ranges, with a replacement of species in the $2,300-2,500 \mathrm{~m}$ range (Table 1 ). Grallaria ruficapilla was recorded only in the lower half of the transect, whereas G. rufocinerea and G. muchalis were found in the upper half. Grallaria squamigera was recorded only during detailed censuses at La Pastora, but it is known to occur at elevations of $1,800-2,000 \mathrm{~m}$ in 


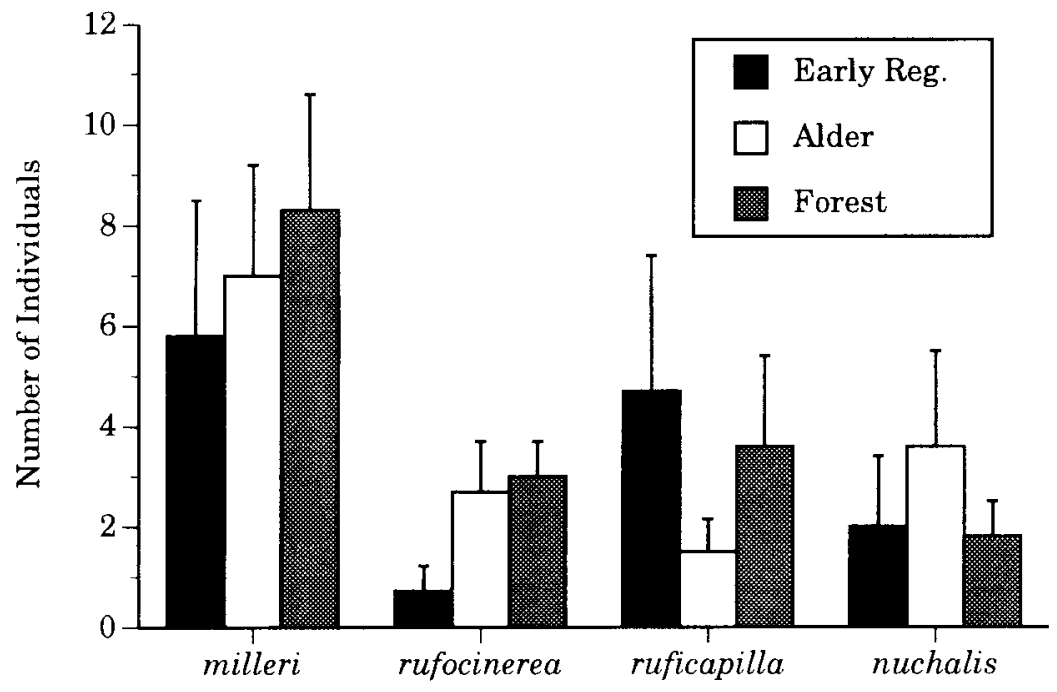

Figure 1. Density, in number of birds per 500-m transect ( $n=10$ transects), of four Grallaria species in three habitats in the range $2,400-2,600 \mathrm{~m}$. Bars represent one standard error.

the same valley (Naranjo 1994), and we assumed that it is present along the lower half of the transect. These four species partially overlapped in the range $2,300-2,600 \mathrm{~m}$, where they completely overlapped with $\mathrm{G}$. milleri, which has been recorded only in the range $2,400-2,600 \mathrm{~m}$ (Table 1 ).

In the area of sympatry, all species used the three habitats sampled. Three lines of evidence indicated that antpittas are territorial: (1) birds usually responded promptly to playbacks, (2) singing birds were present at particular sites throughout the year, and (3) some banded birds were recaptured at the same sites at time intervals of 2 to 12 months. Therefore, we assumed that the mapping of birds along the ro transects represented a census of the territorial bird population during the year of study. Densities of species (in number of birds per $500 \mathrm{~m}$ ) were not significantly different among the three habitats (milleri: $F_{2,29}=0.3$, $P=0.7$; nuchalis: $F_{2,29}=0.5, P=0.6 ; G$. ruficapilla: $F_{2,29}=0.7, P=0.5$ ), except for rufocinerea, which showed a tendency to be more abundant in alder and secondgrowth forest than in early regeneration $\left(F_{2,29}=2.7, P=0.08\right.$; Figure 1). Antpittas used the three habitats in proportion to their occurrence in the landscape (Table 2). Grallaria squamigera was excluded from this analysis because it was found in

Table 2. Numbers of territorial antpittas recorded in three habitats at La Pastora, Ucumarí Regional Park, 2,400-2,600 m, during May 1996-April 1997

\begin{tabular}{lcccc}
\hline Species & Early regeneration & Alder & $\begin{array}{c}\text { Second-growth } \\
\text { forest }\end{array}$ & $\begin{array}{c}P \text {-value* } \\
\text { G. milleri }\end{array}$ \\
G. rufocinerea & 19 & 33 & 32 & $>0.1$ \\
G. ruficapilla & 8 & 11 & 13 & $>0.8$ \\
G. nuchalis & 6 & 9 & 15 & $>0.7$ \\
G. Squamigera & 4 & 15 & 15 & $>0.08$ \\
\hline
\end{tabular}

* Chi-square test. 

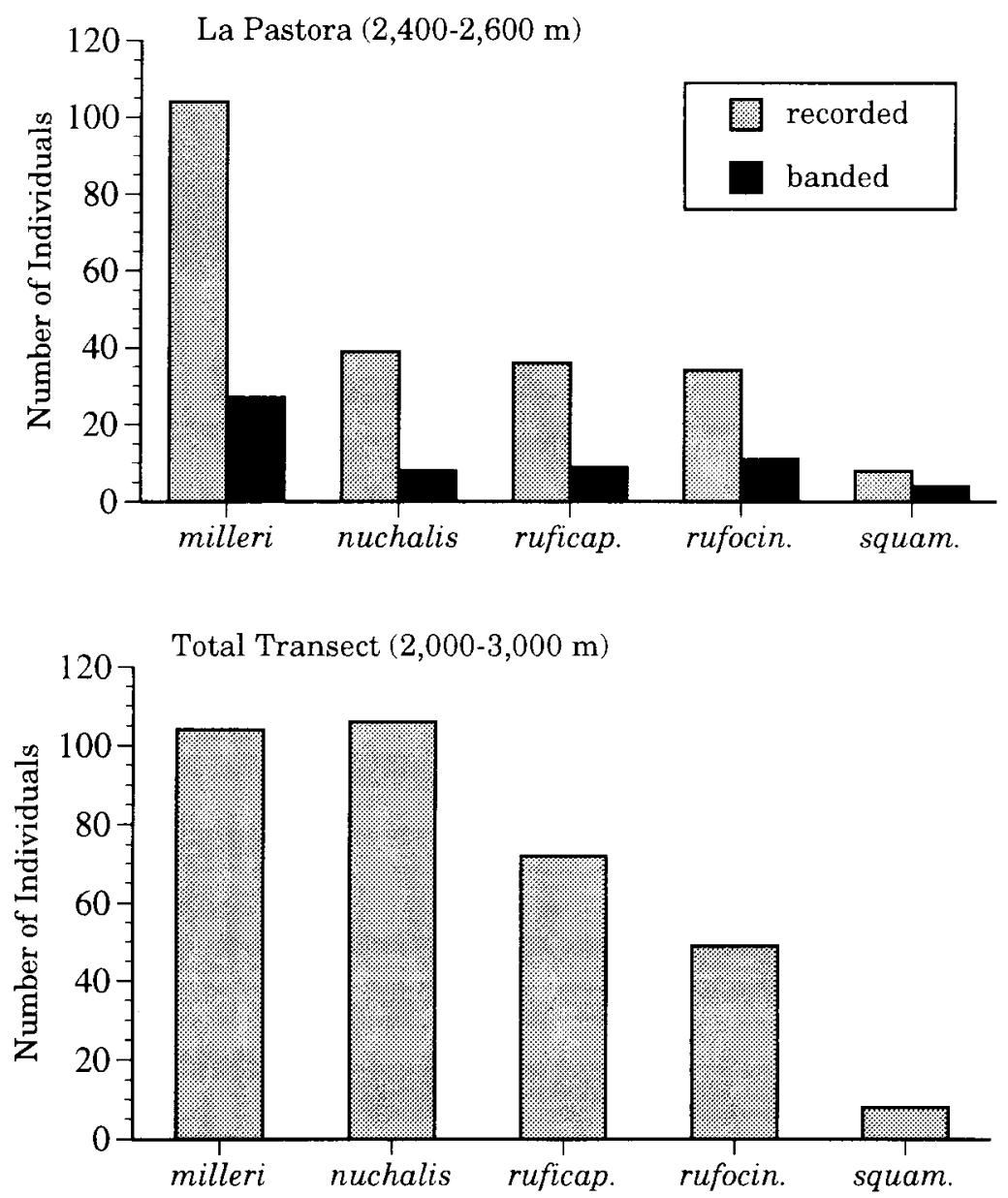

Figure 2. Total number of individuals of five Grallaria species recorded in transects at $2,400-2,600 \mathrm{~m}(6.3 \mathrm{~km})$ and in the whole altitudinal transect between 2,000 and 3,000 $\mathrm{m}$ $(10 \mathrm{~km})$.

low numbers; only eight individuals were located during the year of study (although this scarcity may be a sampling artefact, as this species is the most difficult to detect, because it rarely sings and does not readily respond to playbacks). There were significant differences in density among the five species for the three habitats combined $\left(F_{4,49}=9.0, P<0.001, \mathrm{n}=3\right.$ transects $)$. Grallaria milleri had the highest density (1.3 \pm S.E. of 0.2 individuals per hectare), while $G$. squamigera had the lowest density (0.2 \pm 0.1 inds./ha). Densities of $G$. rufocinerea $(0.8 \pm 0.2), G$. ruficapilla $(0.4 \pm 0.1)$, and G. nuchalis $(0.5 \pm 0.2)$ were not significantly different (Fisher multiple comparison test).

To estimate local abundances, we looked separately at counts of individuals recorded in maps at La Pastora, and along the total altitudinal transect. At La Pastora $(2,400-2,600 \mathrm{~m}), G$. milleri was the most abundant species, with 106 individuals recorded along $6.3 \mathrm{~km}$ of trails (Figure 2). G. squamigera was the least 
Table 3. Measurements of five species of Grallarin of Ucumarí Regional Park (mass in grams, all other measurements in millimetres). Numbers in the table indicate mean \pm S.D. Superscripts with the same letter indicate no significant difference

\begin{tabular}{lrrrrrr}
\hline Species & $n$ & Mass & Tarsus & Culmen & Gape & Wing chord \\
\hline G. rufocinerea & 8 & $44.8 \pm 4.7$ & $46.2 \pm 2.4^{\mathrm{a}}$ & $17.1 \pm 1.5^{\mathrm{c}}$ & $12.8 \pm 1.0$ & $86.7 \pm 3.1^{\mathrm{f}}$ \\
G. milleri & 8 & $52.5 \pm 3.2$ & $46.6 \pm 1.9^{\mathrm{a}}$ & $19.3 \pm 1.4^{\mathrm{c}}$ & $14.0 \pm 1.4$ & $89.6 \pm 3.5^{\mathrm{t}}$ \\
G. ruficipilla & 8 & $82.7 \pm 3.6$ & $54.2 \pm 2.4$ & $23.8 \pm 1.4^{\mathrm{d}}$ & $17.1 \pm 1.1^{\mathrm{e}}$ & $101.6 \pm 1.3$ \\
G. nuchalis & 4 & $101.2 \pm 4.3$ & $60.5 \pm 2.3^{\mathrm{b}}$ & $23.3 \pm 3.1^{\mathrm{d}}$ & $17.1 \pm 2.1^{\mathrm{c}}$ & $117.5 \pm 3.3$ \\
G. squamigera & 4 & $131.6 \pm 3.1$ & $60.7 \pm 0.8^{\mathrm{b}}$ & $30.0 \pm 2.0$ & $17.6 \pm 1.9^{\mathrm{e}}$ & $143.7 \pm 3.1$ \\
\hline
\end{tabular}

abundant, with only eight individuals recorded in the same transects. The other three species had intermediate abundances. Density of $G$. nuchalis was higher in the upper part of its range ( 16.7 individuals per $\mathrm{km}$ of transect between 2,600 and $3,000 \mathrm{~m}$ ) than in La Pastora $(6.5 \mathrm{ind} / \mathrm{km})$. In contrast, G. rufocinerea had a higher density at La Pastora $(5.7 \mathrm{ind} / \mathrm{km}$ ) than in the $2,600-3,000 \mathrm{~m}$ range $(3.7 \mathrm{ind} / \mathrm{km})$. Density of G. ruficapilla was the same at La Pastora than in the lower part of the transect $(2,000-2,400 \mathrm{~m}, 6.0 \mathrm{ind} / \mathrm{km})$. Therefore, when considering the whole altitudinal transect $(2,000-3,000 \mathrm{~m}), \mathrm{G}$. muchalis was as abundant as G. milleri (Figure 2), while abundance of G. ruficapilla doubled, and that of $\mathrm{G}$. rufocinerea increased by $50 \%$ with respect to the $2,400-2,600 \mathrm{~m}$ range.

Body masses of the five Grallaria spp. differed by a factor of three, and all were significantly different (one-way ANOVA, $F_{4,37}=564.0, P<0.001$ ). Differences in body measurements, however, were much smaller (Table 3). Tarsus length, culmen, and wing chord did not increase proportionally to body mass. The two smaller species, G. rufocinerea and G. milleri, did not differ significantly in any of the three measurements, while $G$. nuchalis had the same tarsus length as G. squamigera, but the same bill length as G. ruficapilla (Table 3).

\section{Discussion}

Four or more species of Grallaria antpittas may occur along elevational gradients in the humid Andes from Venezuela south to northern Bolivia, and the morphological distinction between sympatric species is usually clear-cut (Graves 1987). In the case of G. rufula and G. blakei in the Peruvian Andes, in which the two species are morphologically similar, they segregate altitudinally (Graves 1987). At Ucumarí Regional Park five species of Grallaria partially coincide in the 2,0003,000 $\mathrm{m}$ range. Two of the species, $G$. ruficapilla and $G$. squamigera, are sympatric between 2,000 and 2,500 $\mathrm{m}$ (ranges of both species extend down to 1,800 m; Naranjo 1994). They are replaced by another pair, G. rufocinerea and G. nuchalis, in the upper part of the transect, between 2,400 and 3,000 m. In both pairs, species are different in body size. However, these four species and G. milleri overlap in the 2,400-2,600 $\mathrm{m}$ range, where all occur in the same habitats.

We found no statistical differences in patterns of habitat use among the five species in the area of overlap. All species used the three habitat types, young second-growth, 30-year-old mixed forest, and 30-year-old alder forest, in propor- 
tion to their occurrence in the landscape. Therefore, they are not only sympatric but syntopic. It is possible that the observed patterns of habitat use are peculiar to Ucumarí, and not typical of the species along their geographical ranges. The three habitats sampled at La Pastora are the result of relatively recent regeneration, and occur in a complex mosaic of completely interspersed, small patches. The five species of antpitta were widely distributed in this landscape, and overlap of species was almost total. Up to four species were frequently recorded in the same patches, and individuals of two or three species were captured in the same mist-nets several times.

There were, however, some subtle differences that may be biologically significant. Grallaria rufocinerea tended to be more abundant in closed-canopied habitats with an open understorey, than in dense second growth. In contrast, $G$. ruficapilla tended to be near the edges of forest and alder stands, where the understorey is denser, whereas michalis was most frequently found in patches of forest with an open understory. Renjifo and Andrade (1987) report G. nuchalis as "common" (recorded in more than $50 \%$ of observation days) in primary forest and "fairly common" (recorded on 10-50\% of observation days) in secondary growth at $2,800 \mathrm{~m}$ in a neighbouring watershed. We are currently (December 1998) radio-tracking birds to assess home ranges and more finely dissect the patterns of habitat use of individuals, and degree of spatial overlap of the five species.

The spatial overlap of the five species of antpitta raises the possibility of competition for resources, such as nesting sites or food. When similar-sized congeners of some Andean birds occur at the same localities, they tend to segregate altitudinally (Graves 1987, Remsen and Graves 1995a,b). Although antpittas differ widely in body mass, there is overlap in some measures of body size in some of the species. Grallaria milleri is about $20 \%$ heavier than G. rufocinerea but the two species do not differ in tarsus length, bill length, or wing chord (Table 3). Likewise, G. muchalis has longer tarsi than G. mificapilla but both have the same bill length. Therefore, these pairs of species may be competing for the same food items. It is not even clear that a difference in body size will translate into differences in prey type and the five species might be in direct competition. However, the existence of competition depends on there being food limitation, or on one species depressing resource availability for others (Martin 1986), factors that we have not yet determined.

If the five species are competing for resources, this has important implications for habitat use. Presumably, species would first select the habitat where their fitness is maximal, and then settle on suboptimal habitats. If the five species are selecting their habitats independently, the ideal free distribution model (Fretwell and Lucas 1970) predicts that density in the "preferred" habitat will be highest, and will decrease as habitat suitability decreases (Block and Brennan 1993, Wiens 1989). Thus the absence of differences in habitat use would suggest that antpittas do not exhibit a preference for any of the three habitats. If the five species are competing, however, intra- and inter-specific interactions may cause densities in lower-quality habitats to increase to levels equal or higher than those in the preferred habitat (Wiens 1989).

Another factor that may affect densities and patterns of habitat use is the altitudinal distribution. At our study site (La Pastora), at least three of the species are 
at their altitudinal limits and densities of two change with elevation. Numbers of G. nuchalis were higher at higher elevations than at La Pastora, which is at its lower elevational limit. Likewise, patterns of habitat selection of the species may differ towards the centre of their altitudinal distribution. Therefore, patterns of population density and habitat selection of antpittas need to be evaluated at different locations to draw any conclusions about habitat preference.

Our population estimates indicate that in its narrow altitudinal range, G. milleri is the most abundant species. Determining total population size and amount of habitat available in the case of globally threatened species, such as G. milleri, is important for predicting probability of persistence of the population. Original records of G. milleri in its type locality, in the Quindío River watershed just south of Ucumari, are from 2,745 to 3,140 m elevation (Collar et al. 1992). However, we did not detect the species above $2,600 \mathrm{~m}$ in our surveys. The total area of habitat available for G. milleri at Ucumari is undoubtedly larger than the small area we sampled, but we do not know how large. We do not know how plastic the species is in its habitat requirements either, although our data suggest the species does well in a variety of second-growth habitats. Original reports of the habitat where G. milleri was collected in 1911 describe it as humid forest with abundant epiphytes, but apparently some clearings with second-growth vegetation also occurred; it is not clear exactly in which habitat the specimens were obtained (Chapman 1917). Old-growth forest in our study site is restricted to inaccessible slopes, which we did not survey.

Although G. milleri was abundant in our study site, its reduced geographical and altitudinal range makes it extremely vulnerable (Kattan 1992). Even if the species is distributed over all available habitats in the range $2,400-2,600 \mathrm{~m}$ in Ucumari Regional Park and neighbouring watersheds, the total area is small (probably in the range of 5,000 to 10,000 ha) and total population size is likely to be in the range of a few thousand individuals. So far, our study population is the only one known (Kattan and Beltrán 1997). Surveys conducted in the late 1980 and early 1990s failed to find the species in its original localities (Collar et al. 1992). However, G. milleri is difficult to record visually and its calls were unknown. A one-year survey of the avifauna of Ucumarí Regional Park conducted in 1989 failed to detect this species (Naranjo 1994). Our first individual was captured in 1994, after several months of continuous monitoring and mistnetting (Kattan and Beltrán 1997). Now that recordings of this species's calls have been obtained, regional surveys should reveal the status of the species in neighbouring watersheds.

Determining population size of G. rufocinerea is also of interest, as this species is restricted to elevations of $2,400-3,150 \mathrm{~m}$ in the central range of the Colombian Andes, where deforestation has removed much suitable habitat and fragmented the species's range (Collar et al. 1992). Surveys at the Quindio River watershed revealed a density of 1.6 to 5 individuals of this species per $10-\mathrm{km}$ transect between 2,500 and 3,150 m, with higher densities in "primary" forest at lower altitudes (unpubl. data of L. M. Renjifo, cited in Collar et al. 1992). In our censuses we found a density of 5.7 individuals per kilometre in the $2,400-2,600 \mathrm{~m}$ range, versus $3.7 \mathrm{ind} / \mathrm{km}$ in the $2,600-3,000 \mathrm{~m}$ range (Figure 2). Although at our site $\mathrm{G}$. rufocinerea had higher densities in forest than in early regeneration habitats, these forests are 30 years old and far from mature. Therefore, this species exhibits some 
plasticity in habitat use and apparently has higher densities in secondgrowth habitats, a characteristic that should help the species cope with the threat of landscape transformation (Kattan 1992). The possibility exists, however, that the species exhibits geographical variation in population density and habitat selection, possibly in response to interactions with other species. Interestingly, available data suggest that $G$. rufocinerea has higher population densities at its lower elevational limit than at elevations closer to the centre of its altitudinal range.

The concentration of Grallaria antpittas found in the Otún River watershed is remarkable. Recently, G. alleni, another enigmatic species previously known from only two specimens coming from two different localities in the Colombian Andes, was rediscovered in the lower part of Ucumari Regional Park (1800 m; L. M. Renjifo, pers. com.). In addition, it is likely that G. rufula and G. quitensis are present at higher elevations $(>3,000 \mathrm{~m})$ in the same watershed. Therefore, this watershed concentrates six and possibly eight of the nine Grallaria species known from the Central Andes of Colombia (Hilty and Brown 1986), including two species for which these are the only known populations. Our studies have begun to yield information on patterns of habitat use and abundance of these birds, information that will be crucial for habitat management plans to ensure the persistence of these populations.

\section{Acknowledgements}

We thank the Corporación Autónoma Regional de Risaralda (CARDER), the government organization that manages Ucumari Regional Park, and in particular Eduardo Londoño, park director, and Carlos A. Carvajal, manager of La Pastora, for logistical support at the park and for partially funding the project. Additional funds came from the Fondo para la Protección del Medio Ambiente "José Celestino Mutis"-FEN Colombia, the Instituto de Investigación de Recursos Biológicos Alexander von Humboldt, and a grant from the MacArthur Foundation through Wildlife Conservation Society. Thanks to Saulo Usma, Alexandra Aparicio, Victor Serrano, Alberto Galindo and Mónica Parada for help during different phases of the fieldwork. Special thanks to Carolina Murcia for critical advice and for being a source of inspiration during all phases of the project.

\section{References}

Block, W. M. and Brennan, L. A. (1993) The habitat concept in ornithology: theory and applications. Curr. Orn. 11: 35-91.

Chapman, F. M. (1917) The distribution of bird life in Colombia: a contribution to a biological survey of South America. Bull. Amer. Mus. Nat. Hist. 36: 1-729.

Collar, N. J., Gonzaga, L. P., Krabbe, N., Madroño Nieto, A., Naranjo, L. G., Parker, T. A. and Wege, D. C. (1992) Threatened birds of the Americas. The ICBP/IUCN Red Data Book. Third edition (Part 2). Cambridge, U.K.: International Council for Bird Preservation.

Franzreb, K. E. (1981) A comparative analysis of territorial mapping and variable-strip transect censusing methods. Stud. Avian Biol. 6: 164-169. 
Fretwell, S. D. and Lucas, H. L. (1970) On territorial behavior and other factors influencing habitat distribution in birds. I. Theoretical development. Acta Biotheor. 19: 16-36.

Graves, G. R. (1987) A cryptic new species of antpitta (Formicariidae: Grallaria) from the Peruvian Andes. Wilson Bull. 99: 313-321.

Hilty, S. L. and Brown, W. L. (1986) A guide to the birds of Colombia. Princeton, N. J.: Princeton University Press.

Kattan, G. H. (1992) Rarity and vulnerability: the birds of the Cordillera Central of Colombia. Conserv. Biol. 6: 64-7o.

Kattan, G. H. and Beltrán, J. W. (1997) Rediscovery and status of the Brown-banded Antpitta Grallaria milleri in the Central Andes of Colombia. Bird Conserv. Internatl. 7: $367-371$.

Londoño, E. (1994) Parque Regional Natural Ucumarí, un vistazo histórico. Pp. 13-21 in J. O. Rangel, ed. Ucumarí: un caso típico de la diversidad biótica andina. Pereira, Colombia: Corporación Autónoma Regional de Risaralda.

Martin, T. E. (1986) Competition in breeding birds: on the importance of considering processes at the level of the individual. Curr. Orn. 4: 181-210.

Murcia, C. (1997) Evaluation of Andean alder as a catalyst for the recovery of tropical cloud forests in Colombia. Forest Ecol. Mgmt. 99: 163-170.

Naranjo, L. G. (1994) Composición y estructura de la avifauna del Parque Regional Natural Ucumarí. Pp. 305-325 in J. O. Rangel, ed. Ucumari: un caso típico de la diversidad biótica andina. Pereira, Colombia: Corporación Autónoma Regional de Risaralda.

Rangel, J. O. and Garzón, A. (1994) Aspectos de la estructura, de la diversidad y de la dinámica de la vegetación del Parque Regional Natural Ucumarí. Pp. 85-108 in J. O. Rangel, ed. Ucumarí un caso típico de la diversidad biótica andina. Pereira, Colombia: Corporación Autónoma Regional de Risaralda.

Remsen, J. V. and Graves, W. S. (1995a) Distribution patterns and zoogeography of Atlapetes brush-finches (Emberizinae) of the Andes. Auk 112: 210-224.

Remsen, J. V. and Graves, W. S. (1995b) Distribution patterns of Buarremon brush-finches (Emberizinae) and interspecific competition in Andean birds. Auk 112: 225-236.

Renjifo, L. M. and Andrade, G. I. (1987) Estudio comparativo de la avifauna entre un área de bosque andino primario y un crecimiento secundario en el Quindío, Colombia. Pp. 121-127 in H. Alvarez-López, G. Kattan and C. Murcia, eds. Memorias del Tercer Congreso de Ornitología Neotropical. Cali, Colombia: Sociedad Vallecaucana de Ornitología and Universidad del Valle.

Ridgely, R. and Tudor, G. (1994) The birds of South America, 2. The Suboscine Passerines. Oxford: Oxford University Press.

Schulenberg, T. S. and Williams, M. D. (1982) A new species of antpitta (Grallaria) from northern Peru. Wilson Bull. 94: 105-113.

Stiles, F. G. (1992) A new species of antpitta (Formicariidae: Grallaria) from the Eastern Andes of Colombia. Wilson Bull. 104: 389-399.

Stiles, F. G. and Alvarez-López, H. (1995) La situación del tororoi pechicanela (Grallaria haplonota, Formicariidae) en Colombia. Caldasia 17: 607-610.

Wiens, J. A. (1989) The ecology of bird communities, 1. Foundations and patterns. Cambridge: Cambridge University Press.

\section{GUSTAVO H. KATTAN}

Fundación EcoAndina/Wildlife Conservation Society-Colombia Program, Apartado 25527, Cali, Colombia. E-mail: gukattan@cali.cetcol.net.co

J. WILLIAM BELTRAN

Fundación EcoAndina, Apartado 25527, Cali, Colombia. 